\title{
Pengaruh Disiplin Kerja dan Lingkungan Kerja Terhadap Kinerja Karyawan pada PT PLN (Persero) Unit Induk Distribusi Jawa Tengah dan D.I Yogyakarta Unit Pelaksana Pelayanan Pelanggan Salatiga
}

\author{
Gita Dea ${ }^{1}{ }^{*}$, Ocky Sundari ${ }^{2}$, Johnson Dongoran ${ }^{3}$
}

1,2,3 Universitas Kristen Satya Wacana Salatiga

\author{
A R T I C L E I N F O \\ Article history: \\ Received 01 December \\ 2019 \\ Received in revised form \\ 31 December 2019 \\ Accepted 15 January 2020 \\ Available online 26 \\ February 2020

\section{Kata Kunci:} \\ Disiplin Kerja, Lingkungan \\ Kerja, dan Kinerja \\ Karyawan \\ Keywords: \\ Work Discipline, Work \\ Environment, and Employee \\ Performance
}

\begin{abstract}
A B S T R A K
Penelitian ini bertujuan untuk menganalisis pengaruh disiplin kerja dan lingkungan kerja terhadap kinerja karyawan. Objek yang diteliti adalah karyawan perusahaan PT PLN (PERSERO) Unit Induk Distribusi Jawa Tengah Dan D.I Yogyakarta Unit Pelaksana Pelayanan Pelanggan Salatiga. Teknik pengambilan sampel menggunakan metode puposive sampling, yaitu responden yang sudah bekerja lebih dari satu tahun. Penelitian menggunakan data primer dengan instrumen kuesioner. Pengujian dilakukan dengan analisis regresi linier berganda untuk menguji pengaruh variabel disiplin kerja dan lingkungan kerja terhadap kinerja karyawan. Hasil penelitian menunjukkan bahwa disiplin kerja berpengaruh terhadap kinerja karyawan, lingkungan kerja berpengaruh terhadap kinerja karyawan tetapi tidak signifikan, serta disiplin kerja dan lingkungan kerja secara berasama-sama berpengaruh terhadap kinerja karyawan.
\end{abstract}

\section{A B S T R A C T}

This study aims to analyze the effect of work discipline and work environment on employee performance. The object of study was the company employees of PT PLN (PERSERO) Central Java Distribution Main Unit and D.I Yogyakarta Salatiga Customer Service Implementation Unit. The sampling technique uses puposive sampling method, ie respondents who have worked for more than one year. The study uses primary data with a questionnaire instrument. Testing is done by multiple linear regression analysis to test the effect of work discipline and work environment variables on employee performance. The results showed that work discipline has an effect on employee performance, the work environment has an effect on employee performance but is not significant, and work discipline and the work environment have an effect on employee performance.

\footnotetext{
* Corresponding author.

E-mail addresses: 212015207@student.uksw.edu (Gita Dea)
} 


\section{Pendahuluan}

Sumber daya manusia adalah faktor yang sangat sentral dalam organisasi, apapun bentuk dan tujuannya, organisasi dibuat berdasarkan berbagai visi untuk kepentingan manusia. Pentingnya sumber daya manusia dalam suatu organisasi, menuntut setiap organisasi mendapatkan pegawai yang berkualitas dan produktif untuk menjalankan organisasi. Manajemen sumber daya manusia pada era informasi ini, menurut Dessler (2003:36) yaitu: "Strategic Human Resource Management is the linking of Human Resource Management with strategic role and objectives in order to improve business performance and develop organizational cultures and foster innovation and flexibility". Terlihat bahwa para pimpinan organisasi harus mengaitkan pelaksanaan manajemen sumber daya manusia dengan strategi organisasi untuk meningkatkan kinerja serta mengembangkan budaya organisasi yang akan mendukung penerapan inovasi dan fleksibilitas (Kalangi, 2015).

Sumber daya manusia (SDM) merupakan bagian yang memegang peranan penting dalam suatu organisasi. Tanpa adanya sumber daya manusia (SDM) yang berkualitas, suatu organisasi tidak dapat menjalankan kegiatannya dengan baik (Afif, Paramitha, \& Hasiolan, 2016). Suatu organisasi memerlukan sumber daya manusia (SDM) sebagai pengelola sistem untuk mencapai tujuan.Rumondor, Tumbel, \& Sepang (2016) menyatakan manajemen sumber daya manusia sebagai indikator penting pencapaian tujuan organisasi secara efektif dan efisien. Dengan demikian karyawan dituntut untuk memiliki kemampuan dalam menjalankan tugas dan tanggung jawabnya. Afif et al., (2016) juga menunjukkan pentingnya disiplin kerja untuk memberdayakan karyawan sehingga memiliki kemampuan kinerja yang optimal dalam pencapaian tujuan perusahaan.

Kinerja adalah tingkat keberhasilah seseorang atau kelompok orang dalam melaksanakan tugas dan tanggung jawabnya serta kemampuan untuk mencapai tujuan dan standar yang telah ditetapkan Sugiyatmi et al., (2016). Nadhifah, Titisari, \& Dewi (2018) menegaskan bahwa kinerja merupakan kemajuan yang didasari oleh pengetahuan, sikap, dan motivasi dalam menghasilkan suatu pekerjaan. Murty \& Hudiwinarsih (2012) juga menyatakan kinerja merupakan hasil kerja baik kualitas maupun kuantitas yang dihasilkan karyawan atau perilaku nyata yang ditampilkan sesuai dengan tanggung jawab yang diberikan kepadanya. Sukarjati, Minarsih, \& Warso (2016) menyatakan kinerja karyawan merupakan hasil kerja baik kualitas dan kuantitas yang dicapai seorang karyawan dalam melaksanakan tugasnya sesuai dengan tanggung jawab yang diberikan. Berdasarkan pendapat para ahli maka, kinerja karyawan adalah hasil usaha yang diperoleh setiap karyawan dalam melakukan tugas dan kemampuan yang dimilikinya.

Menurut Dhermawan et al., (2012) yang menyatakan bahwa kinerja karyawan secara umum terdiri dari dimensi prestasi kerja yang diidentifikasi sesuai standar penetapan kinerja yang ditetapkan perusahaan. Sugiyatmi et al., (2016) menyatakan bahwa faktor dimensi prestasi kerja terdiri dari unsurunsur pekerjaan karyawan yang dievaluasi. Dimensi ini terdiri dari bermacam-macam karakteristik yang sesuai pengukuran hasil kerja terhadap kinerja karyawan yang terdiri dari kuantitas merupakan jumlah yang diselesaikan, kualitas merupakan manfaat yang dihasilkan, serta ketepatan waktu merupakan kesesuaian dengan waktu yang direncanakan.

Sedarmayanti (2007) menunjukkan faktor-faktor yang dapat mempengaruhi kinerja antara lain : sikap dan mental (motivasi kerja, disiplin kerja, dan etika kerja), tingkat pendidikan, keterampilan, manajemen kepemimpinan, tingkat penghasilan, gaji dan kesehatan, jaminan sosial, iklim kerja, sarana dan prasarana, teknologi, dan kesempatan berprestasi. Selanjutnya kinerja karyawan merupakan catatan perolehan yang dihasilkan karyawan dari pekerjaan tertentu atau kegiataan selama suatu periode waktu tertentu (Hidayat \& Taufiq, 2012). Selain itu pengukuran kinerja karyawan secara umum dapat dilakukan melalui kuantitas kerja, kualitas kerja, pengetahuan tentang pekerjaan, pendapat yang disampaikan, serta perencanaan, dan keputusan yang diambil.

Sejalan dengan penelitian Hidayat \& Taufiq (2012) menunjukkan enam kriteria yang digunakan untuk mengukur kinerja yaitu (1) quality, merupakan tingkat sejauh mana proses atau hasil pelaksanaan kegiatan mendekati tujuan yang diharapkan, (2) quantity, merupakan jumlah yang dihasilkan dari kegiatan yang diselesaikan, (3) time liness, merupakan sejauh mana suatu kegiatan diselesaikan sesuai target waktu yang dikehendaki, (4) cost effectiveness, merupakan sejauh mana penggunan sumber daya untuk mencapai hasil, (5) need for supervision, merupakan sejauh mana suatu pekerjaan dapat dilaksanakan tanpa memerlukan pengawasan atau supervisi untuk mencegah tindakan yang kurang diinginkan dan , (6) interpersonal impact, merupakan sejauh mana karyawan dapat memelihara nama baik dan kerja sama diantara rekan kerja dan bawahan.

Dari urian di atas dapat dikatakan bahwa kinerja karyawan merupakan hasil yang dicapai seorang karyawan dalam melaksanakan tugasnya sesuai dengan tanggung jawab yang diberikan yang diukur berdasarkan kualitas dan kuantitas sesuai standar penetapan perusahaan. Dalam penelitian ini kinerja 
karyawan ditentukan oleh lima indikator yaitu (1) Pekerjaan yang dilakukan sesuai standar, (2) Pekerjaan dilakukan sesuai rencana (planning), (3) Kerjasama dengan rekan kerja, (4) Sikap terhadap pekerjaan dalam tim, serta (5) Kerjasama dalam menyelesaikan pekerjaan.

Sebelumnya, Hidayat \& Taufiq (2012) menunjukkan sumber daya manusia (SDM) merupakan aset yang perlu ditingkatkan secara efektif dan efisien sehingga terwujud kinerja yang optimal. Hal ini menunjukkan organisasi perusahaan perlu mampu menciptakan situasi dan kondisi yang mendorong dan memungkinkan karyawan untuk mengembangkan kemampuan dan keterampilan secara optimal, khususnya dalam hal kinerja. Maka organisasi perlu memperhatikan lingkungan kerja dan disiplin.

Dhermawan, Sudibya, \& Utama (2012) meneliti pengaruh motivasi, lingkungan kerja, kompetensi, dan kompensasi terhadap kepuasan kerja dan kinerja karyawan. Hasil penelitian menunjukkan faktor lingkungan kerja berpengaruh terhadap kinerja karyawan. Sejalan dengan itu, Hidayat \& Taufiq (2012) mengkaji pengaruh lingkungan kerja, disiplin kerja serta motivasi kerja terhadap kinerja karyawan. Hasil penelitian menyatakan bahwa lingkungan kerja dan disiplin kerja berpengaruh pada kinerja karyawan. Menurut Hidayat \& Taufiq (2012), lingkungan kerja merupakan segala sesuatu yang ada di sekitar dan mempengaruhi karyawan dalam menjalankan tugas yang dibebankan. Hal ini menunjukkan faktor lingkungan kerja mampu mempengaruhi kinerja karyawan dalam mengoptimalkan produktivitas. Menurut Suwondo \& Sutanto (2015) setiap perusahaan memiliki lingkungan kerja yang berbeda-beda sehingga dapat mempengaruhi kinerja karyawan.

Sebaliknya penelitian Arianto (2013) menunjukkan lingkungan kerja tidak berpengaruh terhadap kinerja karyawan, hal ini dikarenakan lingkungan fisik dan lingkungan psikis kurang memadai dan kurang mendukung bagi kegiatan pegawai. Sempitnya ruang untuk bekerja, kamar mandi yang tidak bersih, lahan parkir yang terbatas serta halaman yang tersedia tidak memadai sehingga berdampak pada kinerja karyawan. Sama halnya dengan penelitian Herawati (2015) juga menunjukkan hasil pengujian hipotesi pada variabel lingkungan kerja memiliki nilai sig. sebesar $0,581(0,581>0,05)$ yang berarti lingkungan kerja tidak berpengaruh terhadap kinerja karyawan.

Selain lingkungan kerja, disiplin kerja juga dianggap memiliki pengaruh terhadap kinerja karyawan. Penelitian tentang disiplin kerja yang dilakukan oleh Hidayat \& Taufiq (2012), Sajangbati (2013), Runtunuwu, Lapian, \& Dotulong (2015), Sidanti (2015), Suwondo \& Sutanto (2015), Rumondor et al., (2016), Afif et al., (2016), Sugiyatmi, Minarsih, \& PT (2016), serta Primandaru, Tobing, \& Prihatini (2018) menunjukkan disiplin kerja berpengaruh positif terhadap kinerja karyawan. Sebaliknya penelitian Arianto (2013) disiplin kerja juga tidak berpengaruh terhadap kinerja karyawan. Pandangan ini menjelaskan bahwa suatu kerelaan dan kesediaan seseorang dalam menaati peraturan-peraturan yang berlaku tanpa paksaan, belum dapat meningkatkan kesadaraan karyawan untuk menaati semua peraturan dan peningkatan kinerja karyawan. Penelitian Herawati (2015) juga menunjukkan hasil pengujian hipotesi pada variabel disiplin kerja memiliki nilai sig. sebesar $0,294(0,294>0,05)$ yang berarti disiplin kerja tidak berpengaruh terhadap kinerja karyawan.

Disiplin kerja merupakan salah satu bentuk pengelolan sumber daya manusia (SDM) yang baik untuk menunjang kualitas SDM dan merupakan bentuk ketaatan terhadap aturan, baik tertulis maupun tidak tertulis yang telah ditetapkan selain itu, disiplin kerja merupakan motivasi seorang individu untuk mempunyai komitmen yang tinggi dalam mencapai tujuan organisasi (Sajangbati, 2013). Sikap, nilai-nilai serta motivasi individu merupakan faktor yang paling dominan dalam mempengaruhi disiplin kerja agar harapan karyawan dapat tercapai (Dhermawan, Sudibya, \& Utama).

Disiplin kerja merupakan suatu kondisi atau sikap hormat dalam diri karyawan terhadap peraturan dan ketepatan perusahaan (Sidanti, 2015). Disiplin kerja merupakan ketaatan karyawan terhadap suatu aturan dan ketentuan yang berlaku dalam suatu perusahaan atas dasar adanya kesadaran dan bukan unsur paksaan. Hasibuan (2010) mendefinisikan disiplin kerja sebagai kesadaraan dan kesediaan seseorang menaati semua peraturan dan norma-norma sosial yang berlaku. Menurut Ardiansyah \& Wasilawati (2014) dan Sidanti (2015) dalam disiplin kerja terdapat prosedur yang mengkoreksi atau menghukum bawahan karena melanggar peraturan atau norma sosial yang berlaku. Disiplin yang baik ditunjukkan oleh perilaku karyawan menaati ketentuan yaitu datang tepat waktu, berpakaian rapi, tertib dan teratur sesuai dengan ketentuan perusahaan. Berdasarkan pendapat para ahli maka, disiplin kerja adalah suatu sikap ketaatan terhadap peraturan yang berlaku dalam perusahaan.

Hasil-hasil penelitian tersebut di atas menunjukkan bagaimana pengaruh disiplin kerja dan lingkungan kerja terhadap peningkatan kinerja karyawan. Penelitian-penelitian terdahulu menunjukkan hasil yang berbeda dan memiliki ketidakkonsistenan hasil penelitian sehingga penelitian ini akan menguji kembali pengaruh disiplin kerja dan lingkungan kerja terhadap kinerja karyawan.

Permasalahan yang timbul terkait kinerja karyawan di PT PLN (PERSERO) Unit Induk Distribusi Jawa Tengah dan D.I Yogyakarta Unit Pelaksana Pelayanan Pelanggan Salatiga yaitu karyawan yang sering terlambat masuk kantor, tidak kembali tepat waktu setelah jam istirahat, kurang kondusifnya suasana 
saat bekerja, ruangan yang tidak ditata dengan baik sehingga menghambat pergerakan pegawai saat beraktifitas. Kurangnya kinerja pegawai akan berakibat kurang lancarnya pelaksanaan kerja, sehingga dapat mengakibatkan sering tertundanya penyelesaian pekerjaan yang menjadi tanggung jawab para pegawai. Berdasarkan dari latar belakang yang sudah dijelaskan di atas, maka penelitian rancangan tugas akhir yang akan dilakukan berjudul "Pengaruh Disiplin Kerja dan Lingkungan Kerja Terhadap Kinerja Karyawan Pada PT PLN (PERSERO) Unit Induk Distribusi Jawa Tengah dan D.I Yogyakarta Unit Pelaksana Pelayanan Pelanggan Salatiga."

\section{Metode}

Populasi penelitian adalah seluruhan karyawan PT PLN (PERSERO) Unit Induk Distribusi Jawa Tengah dan D.I Yogyakarta Unit Pelaksana Pelayanan Pelanggan Salatiga sebanyak 42 orang karyawan. Pengambilan sampel menggunakan metode purposive sampling, yaitu responden yang sudah bekerja lebih dari satu tahun.

Data penelitian menggunakan data primer dengan instrumen kuesioner untuk mengumpulkan informasi terkait disiplin kerja dan lingkungan kerja. Kuesioner penelitian berisi indikator pada masingmasing variabel penelitian yaitu variabel disiplin kerja, variabel lingkungan kerja dan variabel kinerja karyawan. Pertanyaan yang diajukan kepada responden dikelompokan menjadi 4 bagian yaitu identitas responden, indikator disiplin kerja, indikator lingkungan kerja, dan indikator kinerja karyawan. Penelitian menggunakan skala likert dengan pernyataan jawaban sangat tidak setuju sampai sangat setuju terhadap masing-masing pertanyaan pada setiap indikator. Seluruh jawab dari responden kemudian diberi skor sesuai bobot masing-masing diolah dan di analisis pada setiap ateam pertanyaan pada kuesioner.

Metode analisi data adalah teknik statistik untuk mendapatkan informasi relevan yang terkandung dalam data dan menggunakkan hasilnya untuk memecahkan suatu masalah (Sujarweni, 2015). Penelitian ini akan menguji hipotesis dan menjelaskan pengaruh antara variabel disiplin dan variabel lingkungan kerja terhadap variabel kinerja karyawan. Selain itu, pengujian statistik menggunakan teknik analisis regresi linier berganda untuk menguji pengaruh antara variabel satu dan variabel yang lain. Dalam penelitian ini yang menjadi variabel dependen adalah disiplin kerja dan lingkungan kerja serta variabel independen adalah kinerja karyawan.

Analisis deskriptif penelitian menyajikan data mengenai karakteristik responden seperti jenis kelamin, usia, pendidikan terakhir, lama bekerja, dan jabatan. Sedangkan pengujian hipotesis menggunakan uji validitas, uji reliabilitas, uji normalitas, uji asumsi klasik ( uji hetroskedastisitas), serta uji regresi linier berganda, dengan model persamaan regresi linier sebagai berikut (Runtunuwu et al., 2015):

$\mathrm{KK}=\mathrm{a}+\mathrm{b}_{1} \mathrm{DK}_{1}+\mathrm{b}_{2} \mathrm{LK}_{2}+\mathrm{e}$

Keterangan:

$\mathrm{KK}=$ Variabel Kinerja Karyawan

a $\quad=$ Konstanta

$\mathrm{b}_{1} \mathrm{DK}_{1}=$ Variabel Disiplin Karyawan

$\mathrm{b}_{2} \mathrm{LK}_{2} \quad=$ Variabel Lingkungan Kerja

e $\quad=$ Residual/error

\section{Hasil dan pembahasan}

Responden dalam penelitian ini adalah karyawan di PT PLN (PERSERO) Unit Induk Distribusi Jawa Tengah dan D.I Yogyakarta Unit Pelaksana Pelayanan Pelanggan Salatiga. Proses penyebaran kuesioner dilakukan dengan memberikan kuesioner secara langsung kepada karyawan mulai 27 - 30 September 2019. Jumlah kuesioner yang di bagikan sebanyak 42 kuesioner, tingkat pengambilan kuesioner sebanyak 30 kuesioner $(71,4 \%)$. Seluruh kuesioner yang kembali dapat diolah dan dapat dijadikan sampel penelitian. Rincian karakteristik responden penelitian akan dijelaskan dalam Tabel 2 berikut:

Tabel 2. Karakteristik Responden

\begin{tabular}{cllrr}
\hline No & Karakteristik & \multicolumn{1}{c}{ Keterangan } & Jumlah & Persentase \\
\hline 1 & Jenis Kelamin & Laki-laki & 14 & $46,6 \%$ \\
& & Perempuan & 16 & $53,3 \%$ \\
2 & \multirow{2}{*}{ Usia } & $22-30$ & 13 & $43,3 \%$ \\
& & $30-40$ & 12 & $40 \%$ \\
& & $40-50$ & 2 & $6,7 \%$
\end{tabular}




\begin{tabular}{|c|c|c|c|c|}
\hline \multirow{3}{*}{3} & \multirow{3}{*}{ Pendidikan Terakhir } & $50>$ & 3 & $10 \%$ \\
\hline & & SMA & 10 & $33,3 \%$ \\
\hline & & D3 & 5 & $16,7 \%$ \\
\hline \multirow{4}{*}{4} & \multirow{4}{*}{ Lama Bekerja } & $\mathrm{S} 1$ & 15 & $50 \%$ \\
\hline & & $1-5$ & 11 & $36,7 \%$ \\
\hline & & $6-10$ & 5 & $16,7 \%$ \\
\hline & & $11-15$ & 10 & $33,3 \%$ \\
\hline \multirow{5}{*}{5} & \multirow{5}{*}{ Jabatan } & $16-20$ & 0 & 0 \\
\hline & & $20>$ & 4 & $13,3 \%$ \\
\hline & & Staf & 18 & $60 \%$ \\
\hline & & Supervisor & 8 & $26,7 \%$ \\
\hline & & Manajer & 4 & $13,3 \%$ \\
\hline
\end{tabular}

Tabel 2 memberikan informasi responden penelitian 53,3\% berjenis kelamin perempuan dan $46,6 \%$ berjenis kelamin laki-laki. Sebagian besar responden berusia 22-30 tahun (43,3\%), dengan pendidikan terakhir S1 (50\%) dan 60\% responden memiliki jabatan sebagai staf perusahaan tersebut dengan lama bekerja antara 1 sampai 5 tahun (36\%). Dari hasil pengolahan data terlihat pada Tabel 3 menunjukkan disiplin kerja memiliki nilai minimum sebesar 25,00 dan nilai maximum sebesar 35,00 dengan nilai rata-rata 30,2000, Lingkungan kerja memiliki nilai minimum sebesar 27,00 dan nilai maximum sebesar 35,00 dengan nilai rata-rata 32,0667, dan kinerja karyawan memiliki nilai minimum sebesar 21,00 dan nilai maximum sebesar 30,00 dengan nilai rata-rata 25,8000. Perhitungan statistics descriptive penelitian terlihat pada tabel di bawah ini:

Tabel 3. Descriptive Statistics

\begin{tabular}{lcrrrr}
\hline & N & Minimum & Maximum & Mean & Std.Dev \\
\hline Disiplin Kerja & 30 & 25,00 & 35,00 & 30,2000 & 3,08947 \\
Lingkungan Kerja & 30 & 27,00 & 35,00 & 32,0667 & 2,51798 \\
Kinerja Karyawan & 30 & 21,00 & 30,00 & 25,8000 & 2,79655 \\
Valid N (listwise) & 30 & & & & \\
\hline
\end{tabular}

Sumber: Data Primer diolah, 2019

Uji validitas dilakukan dengan tujuan untuk mengetahui apakah kuesioner yang dibagikan kepada responden berisi pertanyaan yang valid dan dapat dipercaya serta memberikan hasil yang konsisten dalam uji reliabilitas. Dari tabel 4, tabel 5, dan tabel 6 dapat dilihat bahwa pertanyaan dalam variabel disiplin kerja, lingkungan kerja, dan kinerja karyawan dinyatakan valid karena $r$ hitung $>r$ tabel $(0,312)$. Dengan hasil tersebut maka dapat diambil kesimpulan pertanyaan yang ada dalam kuesioner penelitian ini mampu menggambarkan sesuatu yang akan diukur oleh kuesioner tersebut.

Tabel 4. Uji Validitas Variabel Disiplin Kerja

\begin{tabular}{lccc}
\hline \multicolumn{1}{c}{ Korelasi Antara } & $\begin{array}{c}\text { Nilai } \\
\text { Korelasi }\end{array}$ & Keterangan & Kesimpulan \\
\hline Saya datang ke tempat kerja tepat pada waktunya & 0,569 & r Tabel $=0,312$ & Valid \\
$\begin{array}{l}\text { Saya pulang kerja sesuai dengan waktu yang telah } \\
\text { ditentukan }\end{array}$ & 0,390 & r Tabel $=0,312$ & Valid \\
$\begin{array}{l}\text { Saya menggunakan fasilitas kantor dan peralatan } \\
\text { kantor dengan baik }\end{array}$ & 0,746 & r Tabel $=0,312$ & Valid \\
$\begin{array}{l}\text { Saya dapat menyesuaikan diri terhadap prosedur } \\
\text { kerja di tempat kerja }\end{array}$ & 0,787 & r Tabel $=0,312$ & Valid \\
$\begin{array}{l}\text { Saya menyelesaikan tugas sesuai waktu yang telah } \\
\text { ditentukan }\end{array}$ & 0,682 & r Tabel $=0,312$ & Valid \\
Saya menjalankan aturan organisasi dengan baik & 0,787 & r Tabel $=0,312$ & Valid \\
\hline
\end{tabular}


Tabel 5. Uji Validitas Variabel Lingkungan Kerja

\begin{tabular}{lccc}
\hline \multicolumn{1}{c}{ Korelasi Antara } & Nilai Korelasi & Keterangan & Kesimpulan \\
\hline $\begin{array}{l}\text { Menurut saya lingkungan kerja yang kondusif } \\
\text { sangat mendukung kelancaran pelaksanaan }\end{array}$ & 0,538 & $\mathrm{r}$ Tabel $=0,312$ & Valid \\
$\begin{array}{l}\text { Saya selalu giat bekerja dengan kondisi ruang } \\
\text { kerja yang nyaman }\end{array}$ & 0,556 & $\mathrm{r}$ Tabel $=0,312$ & Valid \\
$\begin{array}{l}\text { Perlengkapan kerja yang ada di bagian tempat } \\
\text { saya bekerja telah membantu pelaksanaan } \\
\text { tugas }\end{array}$ & 0,537 & $\mathrm{r}$ Tabel $=0,312$ & Valid \\
$\begin{array}{l}\text { Saya selalu membangun hubungan kerja baik } \\
\text { dengan pimpinan }\end{array}$ & 0,602 & $\mathrm{r}$ Tabel $=0,312$ & Valid \\
$\begin{array}{l}\text { Saya selalu membangun hubungan kerja } \\
\text { dengan sesama rekan kerja }\end{array}$ & 0,567 & $\mathrm{r}$ Tabel $=0,312$ & Valid \\
$\begin{array}{l}\text { Menurut saya, komunikasi yang baik dengan } \\
\text { pimpinan membantu kelancaran pelaksanaan } \\
\text { pekerjaan }\end{array}$ & 0,690 & $\mathrm{r}$ Tabel $=0,312$ & Valid \\
$\begin{array}{l}\text { Menurut saya komunikasi yang baik dengan } \\
\text { rekan kerja membantu kelancaran } \\
\text { pelaksanaan pekerjaan }\end{array}$ & 0,362 & $\mathrm{r}$ Tabel $=0,312$ & Valid \\
\hline
\end{tabular}

Tabel 6 . Uji Validitas Variabel Kinerja Karyawan

\begin{tabular}{lccc}
\hline \multicolumn{1}{c}{ Korelasi Antara } & Nilai Korelasi & Keterangan & Kesimpualan \\
\hline $\begin{array}{l}\text { Hasil kerja yang saya lakukan sesuai } \\
\text { dengan standar kerja }\end{array}$ & 0,659 & $\mathrm{r}$ Tabel $=0,312$ & Valid \\
$\begin{array}{l}\text { Hasil kerja yang saya lakukan sesuai } \\
\text { rencana (planning) }\end{array}$ & 0,754 & $\mathrm{r}$ Tabel $=0,312$ & Valid \\
$\begin{array}{l}\text { Saya mampu bekerjasama dengan rekan } \\
\text { kerja }\end{array}$ & 0,794 & $\mathrm{r}$ Tabel $=0,312$ & Valid \\
$\begin{array}{l}\text { Saya mampu bekerjasama dengan tim } \\
\begin{array}{l}\text { Saya melaksanakan tugas dan tanggung } \\
\text { jawab yang diberikan dalam tim }\end{array}\end{array}$ & 0,742 & $\mathrm{r}$ Tabel $=0,312$ & Valid \\
$\begin{array}{l}\text { Saya bersikap positif terhadap tanggung } \\
\text { jawab yang diberikan }\end{array}$ & 0,709 & $\mathrm{r}$ Tabel $=0,312$ & Valid \\
& 0,717 & $\mathrm{r}$ Tabel $=0,312$ & Valid \\
\hline
\end{tabular}

Tabel 7. Uji Reliabilitas

\begin{tabular}{lccc}
\hline \multicolumn{1}{c}{ Korelasi Antara Nilai } & Cronbach's Alpha & Keterangan & Kesimpulan \\
\hline Disiplin Kerja & 0,857 & 0,600 & Reliabel \\
Lingkungan Kerja & 0,809 & 0,600 & Reliabel \\
Kinerja Karyawan & 0,900 & 0,600 & Reliabel \\
\hline
\end{tabular}

Dari hasil pengolahan data yang terlihat pada tabel 7, nilai Cronbach's Alpha untuk variabel disiplin kerja $0,857>$ dari 0,600 , lingkungan kerja $0,809>$ dari 0,600 , dan kinerja karyawan $0,900>$ dari 0,600 yang artinya semua variabel dalam penelitian ini reliabel.

Pada tahap ini akan dijelaskan hasil pengujian normalitas, multikolinieritas, heteroskedastisitas, koefisien determinasi dan goodness of fit model, serta regresi linier berganda pada masing-masing variabel dan pengaruhnya terhadap kinerja karyawan :

Uji Normalitas dilakukan sebelum data diolah dengan tujuan mengetahui distribusi data variabel yang digunakan dalam penelitian. Data yang baik dan layak digunakan dalam penelitian adalah data yang memiliki distribusi normal. Normal data dapat dilihat dengan menggunakan uji normalitas KolmogorovSmirnov sebagai berikut: 
Tabel 8 . One-Sample Kolmogrov-Smirnov Test

\begin{tabular}{llr}
\hline & & \multicolumn{2}{c}{ Untsandardized Residual } \\
\hline $\mathrm{N}$ & & 30 \\
Normal Parameters & Mean &, 0000000 \\
& Std. Deviation & 2,44042136 \\
Most Extreme Differences & Absolute &, 085 \\
& Positive &, 085 \\
& Negative & -081 \\
Tes Statistic & &, 085 \\
Asymp. Sig. (2-tailed) & &, $200^{\text {c.d }}$ \\
\hline
\end{tabular}

Sumber: Hasil Olah SPSS, 2019

Berdasarkan Tabel 8 diperoleh Asymp. Sig. (2-tailed) sebesar 0,200 yang berarti nilai tersebut lebih besar dari 0,05. Hasil analisis menunjukkan data distribusi normal dengan Asymp. Sig. (2-tailed) lebih dari $5 \%$.

Uji Multikolinieritas diperlukan untuk mengetahui ada tidaknya variabel independen yang memiliki kemiripan antara variabel independen akan mengakibatkan korelasi yang sama kuat. Uji Multikolinieritas digunakan untuk menghindari bias dalam proses pengembalian keputusan kepada pengaruh masingmasing variabel independen terhadap variabel dependen.

Tabel 9 menunjukkan bahwa nial VIF variabel disiplin kerja sebesar 1,095, nilai tolerance sebesar 0,913 , dan nilai VIF variabel lingkungan kerja sebesar 1,095 , nilai tolerance sebesar 0,913 . Semua variabel independen tersebut VIF-nya (Variance Inflation Factor) kurang dari 10 dengan nilai tolerance diatas 0,100. Hal ini menunjukkan model regresi bebas dari asumsi multikolinieritas, atau dengan kata lain tidak ada Multikolinieritas antara variabel independen dalam model regresi. Hasil pengujian Multikolinieritas dapat dijelaskan dalam Tabel 9 berikut:

Tabel 9. Hasil Uji Multikolinieritas

\begin{tabular}{llccl}
\hline \multicolumn{2}{l}{ Collinearity Statistic } & & & \\
\hline Model & & Tolerance & VIF & Kesimpulan \\
\hline 1 & Disiplin Kerja & 0,913 & 1,095 & Bebas Multikolinieritas \\
\hline & Lingkungan Kerja & 0,913 & 1,095 & Bebas Multikolinieritas \\
\hline
\end{tabular}

Uji Heteroskedastisitas menguji terjadinya perbedaan variance residual suatu periode pengamatan ke periode pengamatan yang lain (Sujarweni, 2015). Cara memprediksi ada tidaknya Heteroskedastisitas pada suatu model dapat dilihat dengan pola uji glejser, untuk meregresi nilai absolut residual terhadap variabel bebas. Berikut gambar 2 uji glejser Heteroskedastistitas pada model regresi dalam penelitian ini.

Tabel 10. Hasil Uji Glejser - Heteroskedastisitas

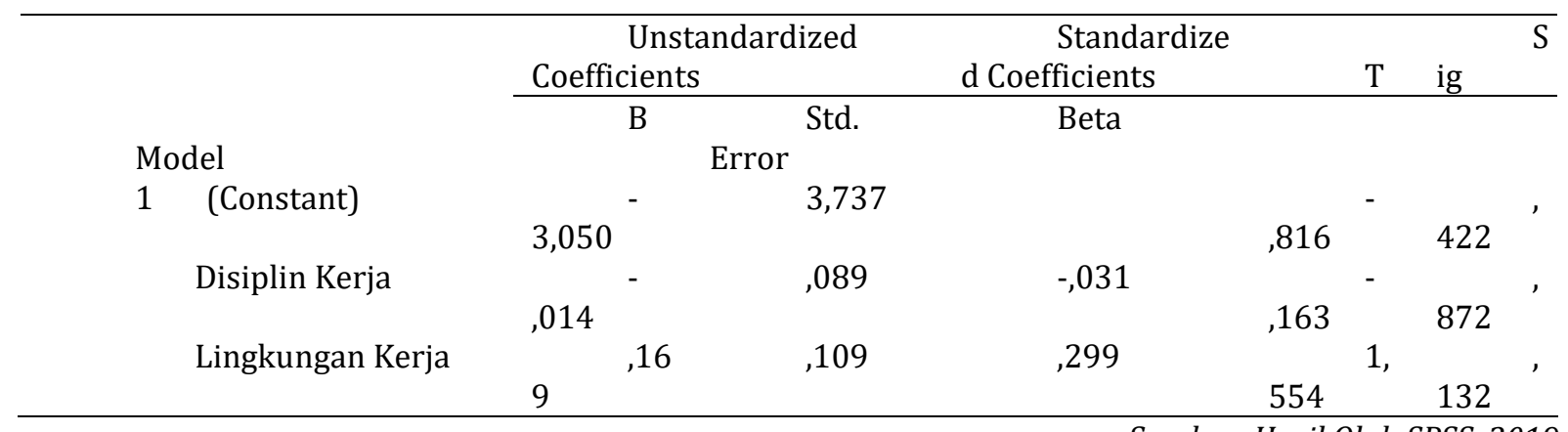

Dari uji glejser pada gambar 2 tersebut menunjukkan bahwa variabel independen yaitu disiplin kerja dan lingkungan kerja semuanya $>0,05$ sehingga, tidak signifikan dan dapat disimpulkan model regresi tidak mengandung Heteroskedastisitas. Hal ini menunjukkan tidak terjadi Heteroskedastisitas 
pada model regresi penelitian ini berdasarkan hasil keseluruhan uji asumsi klasik yaitu Multikolinieritas dan Uji Heteroskedastisitas, dapat disimpulkan nilai parameter yang dihasilkan dalam metode penelitian ini layak karena telah memenuhi asumsi klasik.

Uji Koefisien Determinan digunakan untuk mengetahui seberapa jauh kemampuan model variabel independen (disiplin kerja dan lingkungan kerja) dalam menjelaskan variabel dependen (kinerja karyawan). Berikut adalah hasil pengujian koefisien determinasi dan goodness of fit model yang tersaji pada tabel 10:

Tabel 10. Hasil Uji Koefisien Determinan (R2)

\begin{tabular}{lrrrrr}
\hline $\begin{array}{l}\text { Model } \\
1\end{array}$ & $\mathrm{R}$ & R Square & Adjusted R Square & & Std. Error of the Estimate \\
&, $488^{\mathrm{a}}$ & &, 238 &, 182 & 2,52919 \\
\hline
\end{tabular}

Tampilan output SPSS pada Tabel 10 menunjukkan Adjusted $R$ Square sebesar 0,182. Hal ini berarti 18,2\% variabel disiplin kerja dan lingkungan kerja berpengaruh terhadap kinerja karyawan. Sedangkan sisanya 81,8\% dijelaskan oleh variabel lain diluar model yang digunakan seperti komitmen organisasi, kepuasan karyawan, kompensasi financial dan kompensasi non financial.

Nilai koefisien korelasi (R) pada Tabel 10 sebesar 0,488 menunjukkan hubungan antara variabel independen dengan variabel dependen karena memiliki nilai koefisien korelasi diatas 0,05. Dalam Tabel 10 tersebut juga terdapat Standar Error of the Estimate (SEE) sebesar 2,52919. Semakin kecil nilai SEE akan membuat model regresi semakin tepat dalam memprediksi variabel dependen dengan kinerja karyawan.

Secara keseluruhan variabel disiplin kerja dan linkungan kerja memberi pengaruh terhadap kinerja karyawan. Namun, pada masing-masing variabel tersebut menunjukkan hasil yang berbeda. Pada pengujian regresi linier berganda, variabel lingkungan kerja tidak memberi pengaruh pada kinerja karyawan. Sisanya pada variabel disiplin kerja justru memberikan pengaruh pada kinerja karyawan.

Tabel 11 . Hasil Uji Goodness of Fit Model

\begin{tabular}{llrrrrr}
\hline \multicolumn{1}{c}{ Model } & & Sum of Squares & Df & Mean Square & F & Sig. \\
\hline 1 & Regression & 54,086 & 2 & 27,048 & 4,228 &, $025^{\mathrm{b}}$ \\
& Residual & 172,714 & 27 & 6,397 & & \\
& Total & 226,800 & 29 & & & \\
\hline
\end{tabular}

Sumber: Hasil Olah SPSS, 2019

Berdasarkan Tabel 11, hasil perhitungan statistik menunjukan nilai sig. sebesar 0,025 (kurang dari 0,050 ) nilai tersebut menunjukan bahwa data sampel penelitian diterima (fit) dengan model regresi yang diajukan, artinya semua variabel independen yaitu disiplin kerja dan lingkungan kerja berpengaruh terhadap variabel dependen yaitu kinerja karyawan.

Analisis regresi linier berganda berfungsi untuk mengetahui ada tidaknya pengaruh antara variabel independen dengan variabel dependen (Sujarweni, 2015). Adapun hasil pengolahan data variabel dengan menggunakan SPSS, diperoleh data output model regresi linier pada Tabel 12 berikut:

Tabel 12. Output Model Regresi Linier Berganda

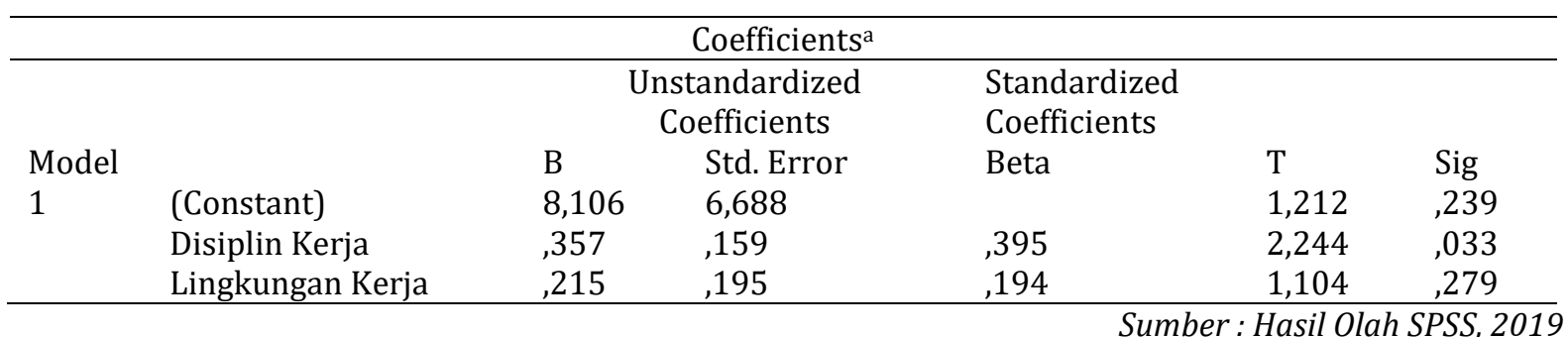

Berdasarkan tabel di atas, dapat dirumuskan bentuk regresi linier berganda yaitu Y= 8,106 + 0,357X1 + 0,215X2 + e. Dapat dilihat bahwa nilai beta (B) masing-masing variabel pada kolom Unstandardized Coefficients menunjukkan nilai positif yaitu disiplin Kerja (0,357), dan lingkungan kerja 
(0,215). Ini menunjukkan bahwa semakin tinggi disiplin kerja dan lingkungan kerja belum tentu mempengaruhi kinerja karyawan. Hasil pengujian regresi linier berganda disajikan pada tabel 13 di bawah ini:

Tabel 13. Hasil Pengujian Regresi Linier Berganda

\begin{tabular}{lcccl}
\hline \multicolumn{1}{c}{ Variabel } & B & Nilai t & Sig & \multicolumn{1}{c}{ Kesimpulan } \\
\hline Disiplin Kerja &, 357 & 2,244 &, 033 & Hipotesis terdukung \\
Lingkungan Kerja &, 215 & 1,104 &, 279 & Hipotesis tidak terdukung \\
\hline
\end{tabular}

Hasil penelitian yang telah dianalisis secara statistik dengan regresi linier berganda mengenai pengaruh disiplin kerja dan lingkungan kerja terhadap kinerja karyawan, menunjukkan beberapa temuan hasil penelitian yang akan dibahas sebagai berikut:

Pengujian variabel disiplin kerja (X1) diperoleh nilai sig. sebesar 0,033 (sig 0,033<0,05). Hal ini menunjukkan bahwa variabel disiplin kerja berpengaruh pada kinerja karyawan. Hasil analisis regresi linier berganda menunjukkan secara parsial variabel disiplin kerja berpengaruh terhadap kinerja karyawan.

Hasil penelitian ini sejalan dengan penelitian Hidayat \& Taufiq (2012), Sajangbati (2013), Runtunuwu et al., (2015), Sidanti (2015), Suwondo \& Sutanto (2015), Rumondor et al., (2016), Afif et al., (2016), Sugiyatmi et al., (2016), serta Primandaru et al., (2018) menunjukkan disiplin kerja berpengaruh positif terhadap kinerja karyawan.

Adanya keinginan untuk berperilaku disiplin dan menaati aturan dalam perusahaan tempat bekerja mendorong seorang karyawan sebagai bentuk peningkatan kinerja (Hidayat \& Taufiq, 2012). Menurut Rumondor et al., (2016) Penelitian ini menunjukkan perilaku disiplin karyawan seperti datang tepat waktu, pulang tepat waktu, menjaga peralatan kantor, penyesuaian diri terhadap prosedur kerja, menyelesaikan tugas sesuai waktu yang ditentukan, dan menjalankan aturan organisasi dengan baik merupakan bentuk disiplin kerja karyawan dalam peningkatan kinerja.

Penelitian ini bertolak belakang dengan Arianto (2013). Penelitian Arianto (2013) menunjukkan bahwa masih ditemukan kurangnya kesadaran karyawan dan kemauan dari karyawan untuk menaati semua peraturan perusahaan sehingga disiplin kerja dianggap bukan sebagai faktor pendorong dalam peningkatan kinerja seorang karyawan.

Pengujian variabel lingkungan kerja (X2) diperoleh nilai sig. sebesar 0,279 (sig=0,279>0,05). Hal ini menunjukkan bahwa variabel lingkungan kerja berpengaruh tetapi tidak signifikan terhadap kinerja karyawan. Hasil analisis regresi linier berganda menunjukkan secara parsial variabel lingkungan kerja berpengaruh tetapi tidak signifikan terhadap kinerja karyawan.

Hasil penelitian ini sejalan dengan penelitian Arianto (2013) menunjukkan lingkungan kerja tidak berpengaruh terhadap kinerja karyawan, hal ini dikarenakan lingkungan fisik dan lingkungan psikis kurang memadai dan kurang mendukung bagi kegiatan karyawan. Sempitnya ruang untuk bekerja, kamar mandi yang tidak bersih, lahan parkir yang terbatas serta halaman yang tersedia tidak memadai sehingga berdampak pada kinerja karyawan. Menurut Arianto (2013) dan Herawati (2015), variabel lingkungan kerja bukan satu-satunya faktor pendorong terjadinya peningkatan kinerja pada karyawan. Lingkungan kerja dianggap sebagai faktor external diri seorang karyawan sehingga faktor lingkungan baik itu lingkungan fisik dan lingkungan psikis tidak dapat secara langsung mempengaruhi peningkatan kinerja pada seorang karyawan.

Pengujian variabel disiplin kerja dan lingkungan kerja terhadap kinerja karyawan diperoleh nilai sig. 0,025 (sig 0,025<0,05). Hal ini menunjukkan bahwa secara simultan variabel disiplin kerja dan lingkungan kerja berpengaruh terhadap kinerja karyawan. Hasil uji goodness of fit model menunjukkan bahwa secara simultan variabel disiplin kerja dan lingkungan kerja berpengaruh terhadap kinerja karyawan.

Hasil penelitian ini sejalan dengan penelitian Sidanti (2015), Runtunuwu et al., (2015), Suwondo \& Sutanto (2015), Primandaru et al., (2018) menunjukkan secara simultan variabel disiplin kerja dan lingkungan kerja berpengaruh positif terhadap kinerja karyawan. Menurut Sidanti (2015) disiplin kerja dan lingkungan kerja merupakan salah satu faktor yang secara bersama-sama dapat mendorong terjadinya peningkatan kinerja pada seorang karyawan. Disiplin kerja merupakan faktor internal yang berasal dari dalam diri seorang karyawan, sedangkan lingkungan kerja yang terdiri dari fisik dan psikis yang merupakan faktor external yang berasal dari luar diri seorang karyawan. Artinya disiplin kerja dan lingkungan kerja mampu menjadi pendorong dalam peningkatan kinerja seorang karyawan. 


\section{Simpulan dan saran}

Penelitian ini meneliti tentang pengaruh disiplin kerja dan lingkungan kerja terhadap kinerja karyawan PT PLN (PERSERO) Unit Distribusi Jawa Tengah Dan D.I Yogyakarta Unit Pelaksana Pelayanan Pelanggan Salatiga.

Berdasarkan hasil analisis data yang telah dilakukan, dapat disimpulkan bahwa:

1. Disiplin kerja berpengaruh terhadap kinerja karyawan PT PLN (PERSERO) Unit Distribusi Jawa Tengah dan D.I Yogyakarta Unit Pelaksana Pelayanan Pelanggan Salatiga. Dengan $\beta$ koefisien sebesar 0,357 dengan nilai sig. sebesar $0,033<0,05$.

2. Lingkungan kerja berpengaruh tetapi tidak signifikan terhadap kinerja karyawan PT PLN (PERSERO) Unit Distribusi Jawa Tengah Dan D.I Yogyakarta Unit Pelaksana Pelayanan Pelanggan Salatiga. Dengan $\beta$ koefisien sebesar 0,215 dengan nilai sig. sebesar $0,279>0,05$.

3. Disiplin kerja dan lingkungan kerja secara berasama-sama berpengaruh terhadap kinerja karyawan PT PLN (PERSERO) Unit Distribusi Jawa Tengah Dan D.I Yogyakarta Unit Pelaksana Pelayanan Pelanggan Salatiga. Dengan nilai Adjusted R Square sebesar 0,182 ( 18,2\%).

Hasil penelitian ini menunjukkan disiplin kerja memberi pengaruh pada kinerja karyawan. Oleh karena itu disiplin kerja merupakan salah satu faktor pendorong peningkatan kinerja karyawan yang berasal dari dalam diri seorang karyawan. Dengan disiplin kerja, seorang karyawan termotivasi dan memiliki komitmen dalam peningkatan kinerjanya. Bentuk disiplin kerja karyawan dapat berupa datang dan pulang ke tempat kerja tepat waktu, menggunakan fasilitas kantor dan peralatan kantor dengan baik, menyesuaikan diri terhadap prosedur kerja, menyelesaikan tugas sesuai waktu yang ditentukan, serta menjalankan aturan organisasi dengan baik.

Selain itu, variabel lingkungan kerja menunjukkan bahwa lingkungan kerja berpengaruh tetapi tidak signifikan terhadap kinerja karyawan ini menunjukkan bahwa lingkungan kerja belum tentu dapat mempengaruh peningkatan kerja seorang karyawan, dan lingkungan kerja dianggap sebagai faktor eksternal yang meliputi lingkungan kerja itu sendiri, rekan kerja dan atasan atau pimpinan. Ini menunjukkan peningkatan kinerja dapat dipengaruhi oleh banyak faktor salah satunya adalah lingkungan kerja walaupun pengaruhnya tidak signifikan.

\section{Daftar Rujukan}

Afif, D. N., Paramitha, P. D., \& Hasiolan, L. B. (2016). Pengaruh Karakteristik Organisasi, Disiplin Kerja Dan Kualitas Kerja Terhadap Efektifitas Kerja Karyawan Dengan Kinerja Karyawan Sebagai Variabel Intervening ( Studi kasus pada PT Hartono Istana Teknolgi Kudus ). Journal of Management, 2(2).

Ardiansyah, \& Wasilawati. (2014). Pengaruh Pengawasan dan Disiplin Kerja terhadap Kinerja Karyawan Badan Pusat Statistik Kabupaten Lampung Tengah. Manajemen Kewirausahaan, 16(2), 153-162.

Arianto, D. A. N. (2013). Pengaruh Kedisiplinan, Lingkungan Kerja Dan Budaya Kerja Terhadap Kinerja Tenaga Pengajar. Jurnal Economia, 9(2), 191-200. https://doi.org/10.21831/economia.v9i2.1809

Dhermawan, A. A. N. B., Sudibya, I. G. A., \& Utama, I. W. M. (2012). Pengaruh Motivasi, Lingkungan Kerja, Kompetensi, Dan Kompensasi Terhadap Kepuasan Kerja Dan Kinerja Pegawai Di Lingkungan Kantor Dinas Pekerjaan Umum Provinsi Bali. Jurnal Manajemen, Strategi Bisnis Dan Kewirausahaan, 6(2), 173-184.

Haryono, T. A., Fathoni, A., \& Yugusna, I. (2016). Pengaruh Gaya Kepemimpinan Demokratis dan Lingkungan Kerja Terhadap Kinerja dan Kedisiplinan Karyawan. Journal Of Management, 2(2), 123.

Hasibuan, M. P. (2010). Manajemen Sumber Daya Manusia. Jakarta: PT Bumi Aksara.

Herawati, V. M. P. (2015). Pengaruh Disiplin, Pendidikan Dan Lingkungan Kerja Terhadap Kinerja Karyawan Di Supermarket Pamella Satu Kota Yogyakarta. Jurnal Manajemen, 5(1), 10-17. https://doi.org/10.1145/3132847.3132886

Hidayat, Z., \& Taufiq, M. (2012). Pengaruh Lingkungan Kerja Dan Disiplin Kerja Serta Motivasi Kerja Terhadap Kinerja Karyawan Perusahaan Daerah Air Minum (PDAM) Kabupaten Lumajang. Wiga, 
2(1), 80-97.

Kalangi, Roosje. 2015. Pengembangan Sumber Daya Manusia Dan Kinerja Aparat Sipil Negara Di Kabupaten Kepulauan Sangihe Provinsi Sulawesi Utara . Jurnal LPPM Bidang EkoSosBudKum Volume 2 Nomor 1 Tahun 2015

Murty, W. A., \& Hudiwinarsih, G. (2012). Pengaruh Kompensasi, Motivasi Dan Komitmen Organisasional Terhadap Kinerja Karyawan Bagian Akuntansi (Studi Kasus Pada Perusahaan Manufaktur Di Surabaya). The Indonesian Accounting Review, 2(02), 215. https://doi.org/10.14414/tiar.v2i02.97

Nadhifah, K., Titisari, P., \& Dewi, P. (2018). Pengaruh Implementasi ISO 9001:2008 Terhadap Kinerja Melalui Lingkungan Kerja Dan Disiplin Kerja Pegawai Pada UPT Perpustakaan Universitas Jember. Bisma Jurnal Bisnis Dan Manajemen, 3(1), 156. https://doi.org/10.17509/jpm.v3i1.9451

Primandaru, D. L., Tobing, D. S., \& Prihatini, D. (2018). Pengaruh Motivasi Kerja Dan Lingkungan Kerja Terhadap Kepuasan Kerja, Disiplin Kerja Dan Kinerja Karyawan Pt. Kereta Api Indonesia (Persero) Daop Ix Jember. Bisma, 12(2), 204. https://doi.org/10.19184/bisma.v12i2.7890

Rumondor, R. B., Tumbel, A., \& Sepang, J. L. (2016). Pengaruh Kepemimpinan, Motivasi, Dan Disiplin Kerja Terhadap Kinerja Pegawai Pada Kanwil Ditjen Kekayaan Negara Suluttenggomalut. Jurnal EMBA, $4(2), 254-264$.

Runtunuwu, H. J., Lapian, J., \& Dotulong, L. (2015). Pengaruh Disiplin, Penempatan Dan Lingkungan Kerja Terhadap Kinerja Pegawai Pada Badan Pelayanan Perizinan Terpadu Kota Manado. Jurnal EMBA, $3(3), 81-89$.

Sajangbati, I. (2013). Motivasi, Disiplin, Dan Kepuasan Pengaruhnya Terhadap Kinerja Pegawai Pt. Pos Indonesia (Persero) Cabang Bitung. Jurnal EMBA, 1(4), 667-678.

Sidanti, H. (2015). Pengaruh Lingkungan Kerja, Disiplin Kerja Dan Motivasi Kerja Terhadap Kinerja Pegawai Negeri Sipil di Sekretariat DPRD Kabupaten Madiun. Jurnal JIBEKA, 9, 10.

Sugiyatmi, Minarsih, M. M., \& PT, E. G. (2016). Pengaruh Motivasi, Gaya Kepemimpin Dan Lingkungan Kerja Terhadap Disiplin Kerja Serta Dampaknya Terhadap Kinerja Karyawan Di Pt Bina San Prima. Journal of Management, 2(2), 10-12.

Sujarweni, W. V. (2015). SPSS Untuk Peneliti. Yogyakarta: Pustaka Baru Press.

Sukarjati, E., Minarsih, M. M., \& Warso, M. M. (2016). Pengaruh Kepemimpinan, Pengembangan Sumber Daya Manusia Dan Kepuasan Kerja Terhadap Kinerja Pegawai Kantor Dinas Pengelolaan Keuangan Dan Aset Daerah Kota Semarang. Journal of Management, 02(02).

Suwondo, D. I., \& Sutanto, E. M. (2015). Hubungan Lingkungan Kerja, Disiplin Kerja, Dan Kinerja Karyawan. Jurnal Manajemen Dan Kewirausahaan, 17(2), 41-59. https://doi.org/10.9744/jmk.17.2.135 